\title{
Postmodern Culture and Public Relations: An Analysis through Campaigns ${ }^{123}$
}

\author{
Beris ARTAN ÖZORAN ${ }^{4}$
}

Submitted by: 02.07 .2021

Accepted by: 11.11 .2021

Article Type: Research Article

\begin{abstract}
Despite the diversity of paradigms in the field of public relations, it is evident that the dominant paradigm in the field is the functional paradigm, which defines public relations as a "management function". It leads to the ignorance of "cultural function" of public relations and becomes an obstacle to the development of the field. By establishing a relationship between public relations and culture, this article addresses public relations as a "cultural intermediary" profession that is influenced by the postmodern culture and (re)produces postmodern culture.In the article, three public relations campaigns determined by purposive sampling were analyzed using critical discourse analysis within the framework of multiple case analysis. How postmodern cultural features do public relations campaigns (re)produce; how they (re)produced the postmodern understanding of consumption, whether they reproduce the concepts of polyphony, equality and freedom by deconstructing modernity was analyzed. As a result, it is found that campaigns re(produce) the individualization, modular identity, spectacle, and simulation features of the postmodern culture of the campaigns and, the postmodern understanding of consumption by attributing "new meanings" to organizations and products. At the same time, it is found that they do not ensure polyphony, equality, and freedom by deconstructing modernity and resisting metanarratives, but rather "pretends" to reproduce them.
\end{abstract}

Keywords: Public Relations, Postmodern Culture, Cultural İntermediary, Multiple Case Study

Atıf: Artan Özoran, B. (2021). Postmodern culture and public relations: An analysis through campaigns. Anadolu Üniversitesi Sosyal Bilimler Dergisi, 21(4), 1051-1070.

\footnotetext{
1 This study does not require ethics committee permission.

${ }^{2}$ I declare that my mentor has waived her name as an author in the article titled "Postmodern Culture and Public Relations: An Analysis through Campaigns".

3 This study was produced from the doctoral thesis titled "Postmodern Culture and Public Relations: An Analysis on Campaigns" carried out in Ankara University Social Sciences Institute under the consultancy of Prof. Dr. Nuran Yildiz.

${ }^{4}$ Ankara University, Faculty of Communication, Public Relations, bartan@ankara.edu.tr, ORCID: 0000-0002-1814-4323
} 


\title{
Postmodern Kültür ve Halkla illişkiler: Kampanyalar Üzerine Bir Analiz
}

\author{
Beris ARTAN ÖZORAN ${ }^{5}$
}

Başvuru Tarihi: 02.07.2021

Kabul Tarihi: 11.11 .2021

Makale Türü: Araştırma Makalesi

\section{Öz}

Halkla ilişkiler alanındaki paradigma çeşitliliğine rağmen, alanda hakim paradigmanın halkla ilişkileri "yönetim işlevi" olarak tanımlayan işlevsel paradigma olduğu görülmektedir. Bu durum halkla ilişkilerin "kültürel işlevinin" gözardı edilmesine neden olmakta ve alanın gelişiminin önünde bir engel oluşturmaktadır. Bu makale halkla ilişkiler ile kültür arasında ilişki kurarak, halkla ilişkileri postmodern kültürden etkilenen ve bu kültürü (yeniden)üreten "kültürel aracı" bir meslek olarak ele almıştır. Makalede amaçlı örneklem ile belirlenen üç halkla ilişkiler kampanyası çoklu vaka analizi çerçevesinde eleştirel söylem analizi kullanılarak incelenmiştir. Halkla ilişkiler kampanyalarının hangi postmodern kültür özelliklerini (yeniden) ürettikleri; postmodern tüketim anlayışını nasıl (yeniden) ürettikleri, moderniteyi yapısöküme uğratarak çokseslilik, eşitlik ve özgürlük kavramların yeniden üretip üretmedikleri araştırılmıştır. Sonuçta kampanyaların postmodern kültürün bireyselleşme, modüler kimlik, gösteri, simülasyon özelliklerini; örgütler ve ürünlere "yeni anlamlar" yükleyerek postmodern tüketim anlayışııı (yeniden) ürettikleri bulunmuştur. Aynı zamanda kampanyaların moderniteyi yapısöküme uğratarak çokseslilik, eşitlik ve özgürlük üretmedikleri ancak bu kavramları üretiyor-muş gibi yaptıkları görülmüş̧ür.

Anahtar Kelimeler: Halkla Ilişkiler, Postmodern Kültür, Kültürel Aracılık, Çoklu Vaka Analizi

\footnotetext{
${ }^{5}$ Ankara Üniversitesi İletişim Fakültesi Halkla İlişkiler ve Tanıtım Bölümü, bartan@ankara.edu.tr, ORCID: 0000-0002-1814-4323
} 


\section{Introduction}

Due to the historical background, functionalist approaches have been dominant in the field of public relations (Edwards and Hodges, 2011, p. 1-2; Gower, 2009, p.31; L'etang, 2012, p. 808). This has resulted in the withholding of the formation of alternative perspectives. In this context, postmodernism can be an alternative field of study for public relations. Postmodernism can be used as an epistemology or an era that defines a specific period for public relations research. Most of the researches associating the concept of "postmodern" with public relations consider postmodern public relations as an alternative to modern public relations. According to them, postmodern public relations has the potential to bring a system that will break the oppressive understanding of modern public relations. It is argued that organizations can have an activist stance through public relations and contribute to democracy through activist and radical policy practices. Public relations can transform the balance of power in favor of the week (Holtzhausen, 2002; Holtzhausen and Rosina, 2009; Allagui, 2017). There are many intersections and reseach fields associating the concepts of "postmodern/postmodernity/postmodernism" and public relations. However, it is seen that most of the studies use postmodern epistemology to discuss the liberating potential of public relations.

On the contrary, in the article public relations is considered as a "cultural intermediary" of postmodern culture within the sociocultural paradigm. "Postmodern culture" is used to describe the new cultural structure that emerged after the 1970s. In this context, the main aim of the article is to research how public relations campaigns are affected by postmodern culture and public relations' role as "cultural intermediary" in transmission, transformation, dissemination, and maintenance of the characteristics of postmodern culture.

In this sense, firstly, postmodern culture and its characteristics were defined. Secondly, the "sociocultural" turn in the field of public relations was analyzed and the "cultural intermediary" role of public relations was discussed. To analyze the "cultural intermediary" role of public relations campaigns three campaigns (Boys Do Cry, Are You Klaus Heidi?,The Impossible Signing Session) were examined using multiple case analysis method.

\section{Postmodern Culture}

"Postmodern" is a controversial concept. It has different definitions under different approaches. Some scholars define "postmodernism" as a period, while others identify it as an epistemology. However, these two approaches are also divided into two groups: affirmative and critical. Another reason for confusion about the concept is that "postmodern" is used to describe transformation and change in various fields such as postmodern art, postmodern politics, postmodern coup.

In this research, "postmodern" is used to describe the transformation of culture after the 1970s. Culture is the "cornerstone of social sciences", such as gravity in physics or medicine in medical sciences (Kroeber and Kluckhahn, 1952, p.3).

UNESCO defined culture as "a whole composed of the distinctive material, spiritual, mental, and emotional characteristics that define a society or social group, encompassing not only science and literature but also lifestyles, basic human rights, values, traditions, and beliefs" (UNESCO, 1982, cited in Oğuz, 2011, p.128). According to O'Sullivan (1994: 68), culture means "the social production and reproduction of emotion, meaning, and understanding". For Harris (1999, p.19), culture is the socially learned lifestyle in societies, and these lifestyles include both thought and behavior. According to Eliot (1987, p.37), culture basically expresses a "lifestyle".

This article is based on Eliot's (1987) definition. It is seen that each historical period produces a unique 'lifestyle' that depends on its own social, economic and political conditions. The changes in culture are not limited to consumption. The change in culture brings a change in many fields such as art, literature and architecture. The 
change in culture means the change in the perception and interpretation of the world, the relationship between individuals, the relationship of individuals to life.

Some features of postmodern culture is below:

\section{- $\quad$ The Rise of The Visual and The Spectacle}

With the development of communication technologies - television, camera, cinema - the world has stepped into a process that can be explained by the rules of "images" and "visual culture" (Parsa, 2004, p.1). In postmodern culture, "seeing" got rid of its equal status with "knowing" and came to be of central importance. Societies increasingly rely on the images presented by visual technologies such as advertisements, photographs, surveillance footage, etc. According to Sartori (2001, p.11), homo sapiens (the man who knows) is replaced by homo videns (the man who sees). Now both working time and leisure time are spent around computers, televisions and digital videos. New technologies and images present new worldviews and interpretations of the world in visual terms. However, it should be remembered that these interpretations are not always innocent (Rose, 2001, p. 2).

The most important thesis in this regard is the "spectacle society", which explains the supremacy of the image that transforms the entire social life into an image (Kosovic, 2011, p.18-19). The spectacle determines the dominant pattern of behavior in a given society. Human beings are part of the spectacle and also concepts such as a commodity, need, history, culture, science have all come under the dominance of the spectacle (Debord, 2006). Best and Kellner (2016) argue that spectacle society has reached another stage with postmodern culture. The spectacle is no longer a control mechanism that keeps people passive. With the development of interactive tools such as computers, multimedia, and virtual reality, subjects take a more active role in the spectacle. It can be said that the increase in the importance of the "visual" and the rise of the "spectacle society" have caused significant changes in the perception of reality.

\section{- Hyperreality and Simulation}

One of the most fundamental differences between modern culture and postmodern culture is the definition of reality. Modern thought gives great importance to "reason." In modernity, reason is the only way to lead people to the "single and universal" truth. In contrast, truth is plural in postmodern thought. Baudrillard explains the new understanding of truth with the concepts of "hyperreality" and "simulation". "Hyperreality" is a concept that emphasizes the disappearance of the distinction between reality, fiction, and imitation (Baudrillard, 2008). In "Perfect Murder" Baudrillard (2012, p.16) wrote about the murder of reality. He said that reality has been expelled from reality and turned into a simulation.

The new society where reality is dead is called simulacrum. There are 4 stages of transition to a new society. In the first phase, words and images are developed as reflections of reality. In the second phase, images begin to embellish, exaggerate and distort reality. In the third and fourth phases, simulation replaces reality and a new symbolic society emerges. Symbols and signs no longer have any relation to facts. Therefore, the only form of reality is "hyperreality" in the new society (Baudirllard, 2014, p.19). In other words, simulation is not a reflection of reality, it replaces reality. It is not an imitation or a parody; it is a representation of reality. It transforms the individual's life into a lifestyle that is fictionalized from day to day. Artificial political and economic agendas, artificial wars are gradually replacing reality (Güzel, 2015, p.75). Hyperreality and simulation also influence consumer behavior. Consumers no longer consume based on "necessity", but they consume the hyperreal "meanings" that organizations create.

\section{- Fragmentation, Individualization and Modular Identity}

While modernism is a project of unity, integrity, and homogeneity; postmodernism rejects all singular, integrative, and reductionist social explanations (Özcan, 2012, p.32). Postmodernism is against metanarratives. 
Postmodernists advocate the destruction of grand narratives and fragmentation to liberate discourse. However, fragmentation has become so ubiquitous that it has become the meta-narrative of postmodernism (Firat, 1991).

Reflections of fragmentation in postmodern culture can be seen at all levels. At the abstract level, fragmentation destroys the integrated view of nature and the philosophy of objective knowledge. At the social level, states, social institutions such as the family and political parties are fragmented (Berthon and Katsikeas, 1998, p.150). At the economic and political levels, fragmentation means the disappearance of dominant ideologies and standards of judgment (Odabaşı, 2012, p.51).

In postmodern culture, society itself is also fragmented. Bauman (2001) and Beck (2011) define the fragmentation of society with the term "individualization". Bauman (2001, p.36,63) states that individualization is no longer an option but a destiny. Individuals float because they are disconnected from the whole. Everything they think, experience, and hope for are personal (Yıldiz, 2013, p.60). Moreover, individuals are also fragmented, which is explained by the concept of "modular identity". A modular individual does not have a predetermined profile. The modular individual has mobile, disposable, and interchangeable characteristics (Bauman, 2000b, p.167-170). As identity is fragmented, individuals switch between the images produced by consumer culture and (re)establish their identities (Binay, 2010, p.20). Consumption is already one of the most important causes of fragmentation. The new understanding of consumption creates a dynamic, variable, and slippery understanding of identity (Bat1, 2015, p.102).

In summary, when considering the characteristics of postmodern culture, these concepts spiral. The rise of the visual and the spectacle, simulation and hyperreality, fragmentation, individualization, modular identity, and the "anything goes" approach are characteristics that influence each other, but are also influenced by each other.

\section{Public Relations as a Cultural Intermediary of Postmodern Culture}

Although there are various paradigms in the field of public relations, the dominant one is the "functional approach" which assumes publics relations as a management function. However, to analyze public relations only from an organizational perspective ignores the fact that it is also a social and cultural practice (Edwards and Hodges, 2011, p.1-2). After the 2000s, the contributions of alternative paradigms in the field of public relations began to increase. "Sociocultural approach" is one of the alternative perspectives. It considers public relations as part of the communicative process in which society constructs its own symbolic and material reality. According to this approach, public relations functions as a means of producing, maintaining, and organizing cultural meanings. Public relations is a social and cultural practice that creates discourses that shape values and beliefs (Edwards and Hodges, 2011, p.1-4). This new understanding of public relations is referred to as the 'cultural turn'. There is an increase in the approaches that examine the position of public relations in society and view it as a profession that changes the structure of society. This approach also considers public relations as a "cultural intermediary" profession.

The term "cultural intermediary" is derived from Pierre Bourdieu's discussion of the "new petty bourgeoisie" (O'Connor, 2015, p.376). Symbolic production is at the heart of the work of the cultural intermediary professions. Symbolic production has great significance in the emergence of modern commodification. Therefore, cultural intermediaries shape both use value and exchange value and seek how to relate these values to individuals' lives through various persuasion and marketing techniques (Negus, 2002, p.502-504). In other words, they shape the tastes of individuals and affect their consumption patterns. As new cultural intermediaries, public relations promote a certain kind of habitus (Edwards, 2012, p.439), that is, a certain lifestyle. They produce representations in the interpretation of production and consumption to structure how publics think, feel and behave (Curtin and Gaither, 2005, p.107). 
However, Edwards (2012, p.442) states that the "cultural intermediary" role of public relations cannot be considered independently of the symbolic power struggle. He says that the "symbolically violent" side of public relations is ignored by most of the researchers. "Symbolic violence" is a concept of Bourdieu that refers to a covert and invisible form of domination that is distinct from physical violence (1991, p.23-24). It is an attempt to create a "way of thinking". When public relations is seen as an intermediary profession that 'produces meaning' through discourse, and when it is seen as operating within and emanating from a particular organization (state, company, NGO), it is possible to see the profession's connection with the concept of "symbolic violence".

If the work of cultural intermediaries includes the production and circulation of information and symbolic materials, then it also involves the hiding, deception and manipulation of information. Cultural intermediaries, especially those who work in marketing and public relations, have a good chance of distorting information, hiding it, and spreading misconceptions. In other words, public relations professionals are not equal mediators for both parties (Negus, 2002, p.504-508). This emphasis raises the question of whether public relations practice "symbolic violence" in favor of the organization.

This discursive struggle forms the basis of public relations. Organizations create symbolic values that reinforce their position and challenge the validity of other perspectives in order to be heard more than their competitors. When the organization's self-interest is not perceived, the business of public relations is successful. Thus, the masses addressed by public relations evaluate the messages created as common reason, common sense, or selfinterest. In this context, it can be seen that the cultural intermediary role of public relations also includes elements of "symbolic violence" (Edwards, 2012, p.441).

The main problem of this article is to discuss whether public relations practices function as a mediator or reproduction mechanism of postmodern culture. In this framework, public relations is considered as a "cultural intermediary" profession. However, the organizational function of public relations has also been included in the study. The article is based on the assumption that public relations is a "cultural intermediary" profession that involves "symbolic violence" that is both influenced by postmodern culture and (re)produces postmodern culture.

\section{Methodology}

The research aims to investigate the role of public relations as a "cultural intermediary" which (re) produces postmodern culture through campaigns. For this purpose, the research investigates the following questions:

1. How do public relations campaigns (re) produce the characteristics of postmodern culture?

2. How publics relatiins campaigns (re)produces the new "postmodern understanding of consumption"?

3. Do campaigns (re)produces polyphony, equality, and freedom to deconstruct modernity?

These questions were analyzed through public relations campaigns. In this context, critical discourse analysis was used in the case analysis. The case study is based on the approach of deep investigation of a particular issue or situation (Yin, 2009, p.23). While this method is concerned with providing detailed information about the situation, it is mainly concerned with uncovering the context in which the phenomenon occurs (Aktaş, 2013, p.188). In this research, the multiple case analysis method was used, which is conducted by examining multiple cases to investigate a general situation. Whether the cases have the same characteristics or not, the analysis of the cases will lead the researcher to a deeper understanding (Zainal, 2007, p.2). The reason for choosing multiple case analyses is that different features of "postmodern culture" can be found in each of the public relations campaigns selected through " purposive sampling". It is not to be expected that the same 
characteristics will be found in each case. By bringing the cases together, the aim is to develop a holistic understanding of the intermediary role of public relations of "postmodern culture".

Each public relations campaign was assumed to be a "discourse" and the method of 'critical discourse analysis' was used to analyze each campaign. The research was conducted within the poststructuralist social science paradigm which argues that all perceptions, concepts and truth cliams are formed through language (Soydan, 2008, p.110-114). Poststructuralists uncover implicit meanings in text by deconstructing metanarratives (Berk and Yildırım, 2015, p.6-7). Therefore, public relations campaigns are deconstructed in this research to find implicit meanings. The aim is to make power relations visible by positioning public relations as a cultural tool that involves "symbolic violence".

Three public relations campaigns were analyzed in this research. In qualitative studies, a relatively small and purposively selected sample may be employed to increase the depth of understanding. Campaigns were chosen with the "purposive sampling" method which is a widely used technic in qualitative research for identifying and selecting information rich cases (Palinkas, et.al, 2015). The campaigns were selected from award-winning campaigns launched after 2010 which have the most data and rich content. Since the research focuses not only the "postmodern culture" in Turkey but on the "postmodern culture" itself, public relations campaigns carried out in different countries have been selected.

In this regard, "Boys Do Cry” (Unilever, Axe), “Are You Klaus Heidi?” (Lufthansa), "Impossible Signing Session" (Bol.com) were analyzed. Due to the nature of the study, informed consent or ethics committee approval was not required.

"Boys Do Cry" campaign was carried out by Axe (Unilever) in 2017 which was realized by Manajans in Turkey. The campaign video was shared via Twitter, Instagram, Youtube, and also on Axe's and Unilever web pages. Can Bonomo, who is the face of the Felis award-winning campaign, appeared on many television and radio programs for the dissemination of the campaign.

“Are You Klaus Heidi?” campaign was carried out by Lufthansa in 2010, Sweden. The campaign was realized in partnership with Burston-Marsteller and DDB Stockholm. Lufthansa's website was used for the Global Sabre award-winning campaign announcements and a micro-website has been created for campaign applications. They also used Twitter, Instagram, and Youtube to disseminate campaign messages.

“The Impossible Signing Session” campaign was carried out by bol.com in 2016, Belgium. The campaign was realized in partnership with DDB-Brussels and Lewis. Bol.com's website, Twitter and Instagram accounts were used for the Cannes Lyon's award-winning campaign.

\section{Results and Discussion}

\section{"Boys Do Cry" Campaign}

The "Boys Do Cry" campaign is the Turkish side of Unilever's global campaign for Axe brand. The campaign is based on a study conducted by Axe with Promundo. According to the study, more than $70 \%$ of men think that "real men" should behave in certain ways. Men feel constricted in social lebels and can't do, feel or say what they want. The purpose of the campaign on Unilever's website as follows: "Society is changing and we are starting to see a shift in the definition of masculinity. The media is talking about it, but there is still a long way to go. Now is the time to use the power of the Axe brand to raise awareness and do something about the dangers of 'toxic' masculinity." The campaign has a social mission, which is to "help men achieve their most attractive state by expressing who they are.". Axe aimed "working to create a society where there is no 'wrong way to be a man,' where there are no labels, where there are no limits to what men can be and do ("Is it ok", 2017). Axe 
wants to contribute to a cultural transformation in society with the campaign. It uses public relations as a "cultural intermediary" and the campaign messages as a tool for cultural change.

For the campaign, Can Bonomo ${ }^{6}$ wrote new lyrics for the song "Boys don't cry" (1985), whose lyrics and music were by Nilufer 7 . The name of the song changed and became: "Boys do cry". The original lyrics, " boys don't cry, wipe your tears". In the campaign song it was changed to "Boys cry, love your tears" and they also added lyrics like "Your tears make you who you are", "Everyone cries whether they're strong or not". The video clip featured different portrayals of men: a man dancing in the bar, a boxer, a biker, a transvestite, a ballet dancer and a butcher. Despite different characteristics, everyone in the clip is crying. It was released on Youtube with the message "Despite those who say boys don't cry, we broke stereotypes with Can Bonomo, we support men to live their emotions freely" (Axe Türkiye, 2017). After the launch, the campaign video shared on social media broke a record with 4.6 million clicks in the first 36 hours, the hashtag \#erkeklerdeağlar was used 14.9 million times, the video received 17,847 comments and became a trending topic on Twitter ("Axe Can Bonomo", 2017).

In modern understanding, there are rules accepted by society about being a "man" and "how to be a man" (Uçan, 2012, p.266). Modern culture has a certain definition of masculinity. From the 18th century, masculinity began to be defined by a set of standards related to appearance and behavior (Beck, 2011, p.157). "Being a man" was associated with not being a wimp, being toothy, being solid as a rock (Çelik, 2016, p.2-3). There are certain patterns that one must follow in order to "be a man", and those who act outside of the patterns become the "others" of the society. On one hand man should fight and dominate others to win, on the other hand they should not express their feelings (like women), avoid intimacy and touching (like homosexuals). From this expression, it is concluded that masculinity is defined by the comparison with "other" identities (Oktan, 2008, p.154). This is a method commonly used by the modern mind. Bauman (2000a) states that modernity has an understanding that defines and excludes the "other" and aims to establish hegemony over the "other" in order to establish itself. On the contrary, postmodern culture glorifies values such as diversity and difference. This understanding has also influenced gender roles (Oktan, 2008, p.156). In postmodern culture, the fiction of "modern masculinity" is threatened and forced to change (Uçan, 2012, p.63, 267). As a result, there is a rejection of the existing understanding of "masculinity" in postmodern culture.

Axe also published a manifesto on its website:

You are a real man!

You can't ask for directions, you can't get lost anyway...

Even if you take the wrong road, you can't turn.

When you support a team, you support it to the death.

You're the pillar of the house, the keeper of honor.

Women can't pay the bill when you're around.

You're a man, you don't cry. You mustn't cry.

That's how you were taught...

Now! Forget what you know.

Don't hold back, live your feelings.

\footnotetext{
${ }^{6} \mathrm{He}$ is a famous Turkish singer in alternative music.

${ }^{7}$ She is a famous Turkish singer and song-writer who has twenty six albums.
} 
Let your tears flow.

Now you're free.

Remember that your tears make you who you are.

Men cry too, my brother, don't wipe away your tears.

"Manifesto" is used for texts that support a particular cause, make arguments, or support a particular lifestyle and have a revolutionary quality (Bora, 2016, p.7). Axe emphasized the behaviors of masculinity in Turkey, such as not asking for directions, supporting a team, being the honor guard, paying bills, not crying. The manifesto encourages men to break these stereotypical patterns and "live their feelings". This manifesto (re)produces characteristics of postmodern culture. According to modernity, "reason" will liberate individuals, not feelings. On the contrary, postmodernists argue that modernity surrounds the individual with an "iron cage" instead of liberating them. The way to overcome this problem is to free the emotions. While the campaign emphasizes the liberation of men through crying, the slogans are "It's you" and "What's your deal?" (Senin olayin ne?). The slogans underline the concept of "difference" and emphasize that every man has his characteristics.

However, the contradictions between the campaign discourses and Axe's philosophy make it necessary to discuss whether the "understanding of masculinity" is really being challenged. On the one hand, the modern understanding of "masculinity" has been opposed and it is emphasized that every man is "special", on the other hand, it is claimed that all these efforts are made to impress women. In the "About Us" section of Axe's website, the brand is introduced as follows, "Axe is designed to make men more confident with its cool and adventurous image... Every aroma is tested on the target audience, real women... Axe has become a brand for men who want to impress women." While men are given the message to "be yourself," on the other hand, they are reminded of their duty to "influence women." In other words, the "liberation" in the campaign is positioned as a means to influence women. Therefore, the only way of influencing women seems to have changed. At the same time, there is a contradiction between the campaign and other communication activities of Axe. For example, the man who uses Axe's shower gel in the Axe Black shower gel commercial is quite different from the male profiles used in the campaign. The commercials use classic, fit and masculine characters. Therefore, it can be said that the brand does not oppose the "understanding of masculinity" but pretends to be against it.

The postmodern world is self-centered and it is seen that the message of "individualization" and "you are important" is (re)produced within the campaign. Funk (2013, p.11-12) describes the new lifestyle as "I am, as much as I am". Over the last 25-35 years, there has been a transition from "you are important" to "I am important". For this reason, this period is defined as "me generation"by some authors such as Twenge (cited in Ylldiz, 2013, p.153). Individuals who are responsible for creating their own identities are looking for the "difference" that will distinguish them from others. Public relations campaigns give the messages saying "you are important", "here is the difference you are looking for!"

Axe's campaign has similar statements. The sentence "Your tears make you who you are" is repeated in both the manifesto and the song. The campaign emphasizes the concept of "difference" by saying "Your tears are special to you like your fingerprints". To show that every tear is different, tears from men shown crying in the clip were taken and turned into bio-art. There are five different tear photos for five different emotions. Can Bonomo's tears as a bio-art form were also displayed at the campaign launch. A necklace from the tears of Can Bonomo's tears was designed by jewelry designer Manuk, and it was said that the designed necklace is one of the symbols of men's liberation. In an interview with Ayşe Arman (2017), Can Bonomo said that they wanted him to cry into a tube to produce the necklace, and he found it difficult to do so, "Yes, it requires a lot of concentration, but the most paradoxical part of the job is this: When you finally cry, you are so happy you will 
laugh." It turns out that the act of crying has also become a commodity, and the tears exhibited do not "really" express the aforementioned feelings.

When the concept of simulation is evaluated in the context of "consumption", it is necessary to talk about "new product". Products now become simulations by acquiring new meanings apart from their own usage areas. Funk (2013, p.29-30) argues that now ascribed emotions, needs, moods, a warm interest, symbols of inner life, success, or advantage. For example, consumers think that those who wear Reebok shoes are active and those who smoke Marlboro have a rich inner world. Axe is a brand that sells deodorant and hair products for men. Deodorant satisfies the need to not sweat and smell good, while hair products satisfy the need for hair care. But that "need" has taken on new meaning through the campaign: Freedom, free-living of emotions, rebellion, breaking the taboos of masculinity.

\section{“Are You Klaus Heidi?” Campign}

"Are you Klaus-Heidi?" campaign created for Luftansa Airlines won an award in the Public Relations category at the 2015 Global Sabre Awards. The campaign was based on a contest and the winner won a new life in Berlin for a year. However, to apply for the competition, participants must legally change their names to "Klauss Heidi". Lufthansa chose Sweden for the campaign because many Swedes have started changing their names to get rid of Swedish surnames ending in "son". And with the 1982 law, Swedes can change their names for almost any reason. "Klaus Heidi" was chosen because Klaus is the most common male name and Heidi is the most common female name in Germany. Therefore, the name is suitable for both genders (DDB Worldwide, 2014)

The main aim of the campaign is to sell the "dream of Berlin" instead of "cheap Berlin". They wanted to give Lufthansa an emotional edge over the competition. They created a video for the campaign and a website for applications. The campaign video starts with the sentence, "Welcome to the preview of your new life." Behind the sentence, there are images like putting suitcases in the trunk, fastening of seat belts, a Luftansa plane taking off. After the plane lands in Berlin, viewers see the winner's "new life." The apartment where Klaus-Heidi will live is shown: "70 square meters, two rooms, and a living room". After a quick display of all rooms, the camera moves downstairs and shows the "new neighbor". In addition, Klaus Heidi will receive a German course, a couple of domestic flights and a Berlin Welcome Card, a bicycle designed for him/her. The video says you can "explore the neighborhood with its local cafes, wonderful restaurants and the cultural, historical and gastronomic opportunities of Berlin and of course the nightlife that makes you wake up tired but happy in the morning." The video ends by saying, "In short, you'll have everything you need to start a new life in Berlin. But you'll have to change your name to Klaus-Heidi. Is this your new life? Are you Klaus-Heidi?"

To become the owner of the house, bike, and other privileges shown in the video, people are asked to officially change their name and apply through the website by writing a motivation letter. The campaign became so successful that 42 Swedes officially changed their name to "Klaus-Heidi". It became news in 90 countries, "mentions" about Luftansa in social media increased by $25 \%$ and Google traffic of luftansa.com increased sharply (DDB Worldwide, 2014).

In the campaign, Lufthansa asked people to change their name, which is one of the most important parts of identity. Fragmentation is one of the characteristics of postmodern culture. It is manifested at the individual level as "modular identity" (Bauman, 2000b), "patchwork identity" or "floating identity" (Funk, 2013, p.63). In postmodern culture, the concepts of uncertainty, diversity, heterogeneity, complexity, relativity and fragmentation are dominant in social conditions, which develop a slippery basis in the construction of identity" (Karaduman, 2010, p.2894).

Modular people have so many characteristics but only for a certain period of time. They adopt them when they need them and discard them when they don't (Bauman, 2000b, p.167). It is possible for them to add new 
features to their identity. Funk (2013, p.62) stated that people in postmodern culture have a new mentality that says "I am this way now, but later it can be different and I live myself in a different way". This shows how fluid identity is in postmodern culture. Moreover, identity has a great importance in the self-definition of individuals in postmodern culture. The campaign video states, "What does a name mean? It's probably the first word you hear. It may be the first word you say. For many of us, it's an important part of who we are." After emphasizing the importance of the name to identity, the question is asked, "Well, what does it take to change the name?" In the context of fluid identity, an important part of identity such as the "name" is as "disposable" and "changeable" as the other characteristics.

At the end of the campaign, 42 people gave up their names just to live in Berlin for a year. However, this is not the only indicator of "modular identity". Klaus-Heidi's characteristics are described as "Berliner" in the campaign. Klaus Heidi has similar characteristics to Berlin. Berlin is a free city and people move to Berlin to accomplish their biggest dreams (Freidman, 2013). Thus, Klaus-Heidi is brave, free, and follows her/his dreams. The person who is selected as Klaus-Heidi will have these characteristics along with the name.

New characteristics of Klaus Heidi are also described in the letter written by the Mayor of Berlin to the KlausHeidis after the campaign: "Dear all Swedish Klaus-Heidis! You are a charmingly crazy, Berlin crazy. That's why you are very suitable here, in Berlin. A city that never sleeps, bustling, with a heart that beats for change, openness and creativity, just like you! What you did was unprecedented. Perhaps only the Swedes could do something like that. Such people are the people Berlin needs"("Swedish Klus Heidi”, 2018). In this speech, it is clear that certain qualities are attributed to the people who applied for the campaign. The name brings with some features such as craziness - but used in a positive sense - open to change, active and creative. Just as a person who buys a Rolex acquires some concepts such as status, ostentation, wealth and prestige with the watch, Klaus-Heidis gains new identity characteristics with the name. Therefore, it can be seen that the campaign is both influenced and (re)produced by the postmodern understanding of identity. Kellner noted that while modern identity is formed in the context of occupation and function in the public sphere, postmodern identity is formed through activities based on appearances, images, and consumption. While modern identity is a serious matter that includes the basic components that show who the person is, postmodern identity is constructed theatrically, as if playing a character on stage (Karaduman, 2010, p.2895). In this campaign, it seems normal to change the name. In addition to the name, these individuals also acquire other identity characteristics "for a period of time".

In postmodernity, everything is temporary. "All interests, skills, spouses, jobs" (Bauman, 2000a, p.74) are discontinuous. For this reason, it is no longer unbearable to give up on all this. The campaign has been influenced and (re)produced the concept of "modular identity", which is one of the postmodern cultural features. Micheal Andersson, who changed his name to Klaus-Heidi, adopted a new identity for only one year.

\section{"Impossible Signing Session" Campaign}

The "Impossible Signing Day" campaign won a Gold Award in the Public Relations category at the 2017 Cannes Lions Awards. The campaign is based on a "Signature Day" at the Antwerp Book Fair in 2016. The Antwerp Book Fair is one of the most popular events in Belgium. More than 150,000 visitors attend this fair in 10 days. The event, in which publishers and bookstores participate with stands, is increasingly seen as a race to get autographs from authors. The most important reason for visitors to attend this event is to get a book signed. The goal of the campaign is to create a buzz in an event that targets traditional booksellers and publishers ("The impossible signing", 2018).

In the campaign, Paul Van Ostaijen, a famous poet who died in 1928, was brought back to life using technology for a book signing. To do this, the author's handwriting was studied in detail and converted into a reproducible font. A robotic arm was created, tuned, and programmed for three months until it perfectly replicated Van 
Ostaijen's handwriting and signature. This allowed Paul Van Ostaijen to sign the new edition of the Music Hall book, which was published exactly 100 years ago. Before the book fair, the bookstore sent a copy of the book signed by Paul Von Ostaijen to prominent journalists to attract press attention, and along with a personal message, journalists were invited to discover the first autograph robot. The campaign had great success. Bol.com's brand awareness increased by $5 \%$ and sales by $40 \%$ after the campaign. Paul Van Ostaijen was the author who signed the most at the Antwerp Book Fair.

Bol.com described the campaign in a video: "There's something magical about getting a book signed. With the stroke of a pen, your book becomes unique. What about all the writers who are no longer with us? What if we could still get their signatures? The Flemish poet Von Ostaijen (1896-1928) was brought back to life for a historic book signing. So he could sign the masterpiece Music Hall that was published exactly 100 years ago. Paul made it even more special for his readers by writing personal messages. This required a robotic arm, normally used for medical purposes, to perfectly reproduce the signature and handwriting of Von Ostaijen. Paul the robot signed books for 12 days and he was not alone. Seven famous writers who couldn't be there also agreed to digitize their manuscripts. Visitors were thrilled to receive personal messages from their 'literary heroes'."

As part of the campaign, the signatures of not only Paul Von Ostaijen but also Nicci French, Paula Hawkings, Andy Griffiths, David Baldacci, David Lagercrantz, and Robert Harris, who are famous in their fields, were replicated (Lewis, 2017). The difference between these writers and Ostaijen is that they are still alive. These writers are individuals who could not be present at the Antwerp Book Fair on the day of the signing, but agreed to have their writings copied by the "robotic arm".

In the promotion of the campaign, it is emphasized that even if your "literary hero" is dead, one can still get a signed book that becomes "unique" with the stroke of a pen. This situation requires the question of how "unique" is evaluated in postmodern culture, the understanding of reality, hyperreality, and simulation. One of the most distinctive features of postmodern culture is the transformation of the understanding of "truth" in modernity. The copies, the imitation begin to be perceived as more real than reality. Baudrillard (2014, p.25) explains this in terms of "simulation". He uses the example of the Lascaux cave. Visits to the cave in France were closed to visitors to protect the cave. However, an exact copy was built five meters next to the original and opened to visitors. Since there is no difference between the original and the copy, both became artificial. In other words, it no longer matters which cave is the real one. The difference between the real one and the copy begins to fade.

Paul Van Ostaijen is no longer alive and cannot attend a signing session. However, the "robotic arm" that is the copy of Ostaijen has signed for him and it is emphasized in the campaign messages that this signature is "unique", just like that of Van Ostaijen. Neither the signature nor the notes in the book are real. However, the longest queue and the most signatures belong to the "robotic arm". One can find the reason for this in Baudrillard's (2014, p.16, 40) statement explaining the difference between "pretending" and simulating. Pretending doesn't harm reality, whereas simulation threatens the distinction between "real" and "imaginary". He explains this in terms of the "perfect murder" of reality.

Not only the signatures of the robotic arm reflect "simulation" in the campaign. Visitors can also write notes for themselves as if they were written by the authors. They write sentences like "to my favorite reader", "I'm am so glad to finally meet you", "sorry for the long wait.". These sentences are not written by the authors, but by the visitors themselves, but with the authors' handwriting and signature. It is impossible for Ostaijen to meet his readers or apologize for keeping them waiting. Through the robotic arm, a new "reality" is produced that seems to be independent of its signifier. Simulation is defined as "a reality devoid of reality". There is no objective reality behind the copy (Bat1, 2015, p.94). In the campaign, there is no "objective" reality behind the robotic arm, which can be considered as a copy. Although the authors have nothing to do with the written 
messages, there are handwritings in the signed books of the visitors. According to Adanır (2015), simulation simply means "showing something that does not exist". There are all indicators of reality in the simulation, but reality itself is not. In the campaign, the handwriting and signatures of the authors are imitated. That is, there are all indicators of truth, but the authors' signatures and their notes are not real. Another noteworthy point is that other writers other than Paul Von Ostaijen are alive. In other words, visitors attending the book fair can request signatures from six authors whose handwritings are imitated by a robotic arm. However, it turns out that people prefer to get signatures from the robotic arm to real authors. Odabaş1 (2012, p.45-46) that images have started to replace reality. Everything has a copy now, and copies are the preferred ones. The strong presentation of copies eliminates the need to see the original. Therefore, individuals are more interested in copies than originals. It can be seen that the campaign is both affected by simulation and (re)produces an understanding of simulation in postmodern culture. As in other campaigns, a "new product" is created in this campaign. Bol.com emerges not only as an online bookstore but also as an innovative, different, technological organization.

\section{Conclusion}

"Public relations" is a controversial field. There are different opinions about whether the field is only an administrative function, whether it has an effect on culture, and what its scope is. These different views and perspectives lead to the formation of different paradigms in the field. Despite the diversity of paradigms, the functional paradigm dominates the field. The dominance of one paradigm prevents different paradigms from feeding each other (Edwards, 2011). Therefore, firstly, it should be recognized that "organization" is a fundamental subject for public relations. Public relations professionals are funded by and have financial ties to specific organizations. These people can't act in a way that is not in the "interest" of the organization. On the other hand, public relations is a profession that is closely related to culture. Public relations is a "cultural intermediary" both affected by the culture and affecting culture. In the context of this paper, it is argued that the culture mediated by public relations is the "postmodern" culture, which is also closely related to consumption. The re-creation, dissemination, and normalization of postmodern culture is very important to make the society "more "fit" for the changing understanding of consumption.

To analyze public relations campaigns as a postmodern cultural intermediary, it is investigated how public relations campaigns (re)produce the characteristics of postmodern culture by multiple case study method. It is found that public relations campaigns (re)produce various features of postmodern culture. Fragmentation manifested as "individualization" on the social level and "modular identity" on the individual level, is (re)produced by campaigns. Campaign messages often repeat the messages "you are special", "you are different", "you can be anything". In postmodern culture, it is of great importance for the individual to find the difference to "make themselves". In the "Boys Do Cry" campaign, expressions such as "your tears make you who you are", "your tears are like your fingerprints, your tears are special to you" are used, and men who can freely express their feelings are seen to be "different" and "unique". "Are you Klaus-Heidi?" is one of the campaigns in which the concept of "modular identity" is most visible. In this campaign, individuals are expected to change their "name", which is one of the most important components of identity, in exchange for sponsoring a year in Berlin. The campaign explains that the name is "an important part of who we are" and promises new character traits alongside the name Klaus-Heidi: open to change, free, brave, following one's dreams.

Another characteristic (re)produced by campaigns is the "spectacle". In spectacle, daily events and familiar things should be presented in a surprising way. Shampoo for washing hair becomes one of the most important sources of self-confidence, whole wheat flour helps to protect nature. Things, experiences and moments that 
are not surprising are invisible (Balaban, 2014). One can see that campaigns are both surprising and interesting: changing your name, signing a book by a dead poet, creating a necklace out of tears.

Simulation is also (re)produced by the campaigns. In "Impossible Signing Session", campaign where the signature and writing of a poet who died years ago was imitated by the robotic arm. Although there were many authors at the book fair, it was the robotic arm that signed the most books. This is an important indicator that copy is becoming more real. While defining postmodernism, Odabaşı (2012, p.45-46) states that images have begun to replace reality. Everything has a fake one and people prefer the copies. In the "Boys Do Cry" campaign, tears are taken from men who play in the video clip and turned into bio-artwork. They named the bio artwork after the characters they played in the video clip, such as greed, loneliness, and regret. However, they are just the actors playing in the clip and they don't really have those emotions. Moroever, Can Bonomo said that it was hard for him to cry and the last time he laughed out loud was after crying in the tube.

Secondly, it is asked how public relations campaigns (re) produce a postmodern understanding of consumption. In postmodern consumption people consume not to meet their needs, but because of the meaning of the product or service. According to Baudrillard (2008), the reason for it is the disappearance of the distinction between real needs and false needs. Consumption has become a means of creating an identity that is "modular" in postmodern culture. What distinguishes goods in the market from each other are now the "meanings" that are attributed to them by communication activities (Odabaşı, 2013, p.152). Objects have gained an indicator value outside of their functions. Therefore objects have become interchangeable with almost unlimited objects with the connotations they gained (Baudrillard, 2008). Public relations is one of the effective activities in creating meanings and hyper-reality within consumption relations. The symbolic meanings and images that emerge as a result of these activities create a hyper-real environment. Thus, a shampoo is stripped of its essential quality and meaning such as a pleasant smell and cleaning feature and get the meaning such as free and active (Bat1, 2015, p.111-112). In the campaigns examined it is seen that they attribute new meanings to organizations. Bol.com is positioned as an innovative and technological brand, Axe as a brand that defies taboos about masculinity and supports the liberation of men, Lutfansa as a "Berlin Crazy" and enjoyable brand.

Most of the researches associating postmodern and public relations were carried out within the framework of the "postmodernist approach to public relations" (Allagui, 2017). This approach discusses the potential of public relations to create polyphony, equality, and freedom to deconstruct modernity. Therefore the answer for the question "does campaigns (re)produces polyphony, equality, and freedom to deconstruct modernity" was searched. It is found that they do not ensure polyphony, equality, and freedom by deconstructing modernity and resisting metanarratives, but rather "pretends" to reproduce them. In the "Boys Do Cry" campaign, Axe critiques the dominant understanding of "being a man." The manifesto highlights various qualities such as "being a guard of honor", "paying the bill", "being the pillar of the house" and these stereotypes are countered by the slogan "forget all you know". However, a closer look at the campaign reveals that the metanarratives are not actually being countered, but only pretended to be countered. The campaign argues that modern understandings of masculinity are being fought. However, Axe has determined the purpose to be "to make boys more assertive over girls with its cool and adventurous image". Emphasizing that every fragrance in their deodorants is tried on women, the brand is positioned as "the assistant of men who want to impress women". Therefore, Axe states that while it aims to liberate boys from the roles of modern masculinity, it also determines its main purpose as influencing women. While men are given the message "Be yourself" through the campaign, men are reminded of their duty to influence women in other communication activities. In other advertisements of the brand, it uses men with classic fit bodies and modern masculinity. It can be seen that different postmodern cultural features come to the fore in each campaign. By having a new name in "Are You Klaus Heidi?" campaign, people were given the opportunity to have a new personality and a new life. But it 
will last only for one year likewise there were not any discourses which create polyphony, equality and, freedom in the "Impossible Signing Day" campaign.

This study focuses on one pillar of a broad field of research that links the fields of "postmodernism" and "public relations". It is believed that further studies linking these two fields will contribute to the diversity of paradigms in public relations.

\section{References}

Aktaş, M. (2013). Halkla ilişkiler araştırmalarında vaka incelemesinin kullanımı üzerine. In M. Aktaş and P. Özdemir (Ed.), Halkla ilişkilerin kazancı (p.187-197). Ankara: De Ki Yayınları.

Allagui, I. (2017). Towards organizational activism in the UAE: A case study approach. PR Rewiev, 43, 258266. doi: 10.1016/j.pubrev.2016.12.007

Arman, A. (2017, 29 April). Can Bonomo: Erkekler kendileriyle barışırlarsa kadınlarla da barışacaklar. Hürriyet. Retrieved from: http://www.hurriyet.com.tr/yazarlar/ayse-arman/can-bonomoerkeklerkendileriyle-barisirlarsa-kadinlarla-da-barisacaklar-40442060

Axe Can Bonomo ile "Erkekler de Ağlar" dedi, 36 saatte 4.6 milyon tık aldı. Marketing Türkiye. (2017 April). Retrieved from: https://www.marketingturkiye.com.tr/haberler/axe-can-bonomo-ile-erkekler-deaglar-dedi-36-saatte4-6-milyon-tik-aldi/

Axe Türkiye. (2017, 29 March). Erkekler de ağlar (Video). Retrieved from: https://www.youtube.com/watch?v=CwLpSiBvnKs

Balaban, U. (2014, March). Bir sonraki temaşayı beklerken: Hadise toplumunda deneyim ve temsil. Bianet. Retrieved from: https://m.bianet.org/bianet/bianet/154442-bir-sonraki-temasayi-beklerkenhadisetoplumunda-deneyim-ve-temsil

Batı, U. (2015). Tüketim davranışları. İstanbul: Alfa Yayınları.

Baudrillard, J. (2008). Tüketim toplumu. İstanbul: Ayrıntı Yayınları.

Baudrillard, J. (2012). Kusursuz cinayet. İstanbul: Ayrıntı Yayınları.

Baudrillard, J. (2014). Simülakrlar ve simülasyon. Ankara: Doğu Batı Yayınları.

Bauman, Z. (2000a). Ölümlülük, ölümsüzlük ve diğer hayat stratejileri. İstanbul: Ayrıntı Yayınları.

Bauman, Z. (2000b). Siyaset arayışı. İstanbul: Metis Yayıncılık.

Bauman, Z. (2001). Bireyselleşmiş toplum. İstanbul: Ayrıntı Yayınları.

Beck, U. (2011). Risk toplumu: Başka bir modernliğe doğru. İstanbul: İthaki Yayınları.

Berk, Y. and Yıldırım, K. (2015). Yapısacılık ile post-yapılsalcılık bağlamında dil ve metinden anlam kurma. Okuma Yazma Eğitimi Araştırmaları, 3, 39-45. Retrieved from: https://dergipark.org.tr/tr/pub/oyea/issue/24685/261032

Berthon, P and Katsikeas, A. (1998). Essai: Weaving postmodernism. Internet Research, 8, 149-155. doi: $10.1108 / 10662249810211610$

Best, S. and Kellner, D. (2016). Debord and postmodern turn: New stages of the spectacle. Retrieved from: https://pages.gseis.ucla.edu/faculty/kellner/Illumina\%20Folder/kell17. htm.

Bora, E. S. (2016). Yapı ve yıkım eylemi olarak mimari manifestolar. (Master thesis, İstanbul Teknik Üniversitesi, İstanbul). Retrieved from: https://polen.itu.edu.tr/handle/11527/14273 
Bourdieu, P. (1991). Language and symbolic power. Cambridge: Polity Press.

Caldiero, C. (2016). Neo-PR: Public relations in a postmodern world. NY: Peter Lang.

Curtin, P. And Gaither, K. (2005). Privileging identity, difference and power: the circuit of culture as a basis for public relations theory. Journal of Public Relations Research, 17, 91-115. doi: 10.1207/s1532754xjprr1702_3

Çelik, G. (2016). Erkekler (de) ağlar!: Toplumsal cinsiyet rolleri bağlamında erkeklik inşası ve şiddet döngüsü. FE Dergisi, 8, 1-12. doi: 10.1501/Fe0001_0000000161

DDB Worldwide. (2014, 2 June). Lufthansa: Are your Klaus Heidi? (Video). Retrieved from: https://www.youtube.com/watch?v=2QAIHqrWtLs

Debord, G. (2006). Gösteri toplumu. İstanbul: Ayrıntı Yayınları.

Edwards, L. and Hodges, M. C. (2011). Public relations, society and culture. New York: Routledge.

Edwards, L. (2011). Defining the object of pr research: a new starting point. Public Relations Inquiry, 1, 7-30. doi: $10.1177 / 2046147$ X11422149

Edwards, L. (2012). Exploring the role of public relations as a cultural intermediary occupation. Cultural Sociology, 6(4), 438-454. doi: 10.1177/1749975512445428

Eliot, T.S. (1987). Kültür üzerine düşünceler. Ankara: Kültür ve Turizm Yayınları.

Firat. (1991). The consumer in postmodernity. In R.H. Holmance and M.R. Solomon (Ed.), Advances in consumer research (p.70-76). USA: Association for Consumer Research.

Freidman, U. (2013, December). How one airline convinced 42 swedes to change their names. The Atlantic. Retrieved from: https://www.theatlantic.com/international/archive/2013/12/how-oneairlineconvinced-42-swedes-to-change-their-names/282346/

Funk, R. (2013). Ben ve biz: Postmodern insanın psikanalizi. İstanbul: YKY.

Gower, K. (2009). Halkla İlişkiler Araştırmaları Yol Ayrımında. In F. Keskin and P. Özdemir (Ed.), Halkla ilişkiler üzerine (p. 31-53). Ankara: Dipnot Yayınları.

Güzel, M. (2015). Gerçeklik ilkesinin yitimi: Baudrillard'ın simülasyon teorisinin temel kavramları. Felsefe ve Sosyal Bilimler Dergisi, 19, 65-84. Retrieved from: https://dergipark.org.tr/tr/pub/flsf/issue/48624/978823

Harris, M. (1999). Theories of culture in postmodern times. London: Altamira Press.

Holtzhausen, D. (2000). Postmodern values in public relations. Journal of Public Relations Research, 2, 93-114. doi: 10.1207/S1532754XJPRR1201_6

Holtzhausen, D. (2002). Towards a Postmodern Agenda for Public Relations. Public Relations Review, 28, 251264. doi:10.1016/S0363-8111(02)00131-5

Holtzhausen, D. and Voto, R. (2009). Resistance from the margins: The postmodern public relations practitioner as organizational activist. Journal of Public Relations Research, 14, 57-84. doi:10.1207/S1532754XJPRR1401_3

Is it ok for guys? Axe says yes. (2017, 10 October). Retrieved from: https://www.unilever.com/news/newsandfeatures/Feature-article/2017/is-it-ok-for-guys-axe-says-yes.html Accessed:10.10.2017.

Karaduman, S. (2010). Modernizmden postmodernizme kimliğin yapisal dönüşümü. Journal of Yaşar University, 17, 2886-2899. Retrieved from: https://dergipark.org.tr/tr/pub/jyasar/issue/19129/202992 
Kosovic, M. (2011). Revisiting the society of the spectacle in the post-9/11 world. Contemporary Issues, 4, 1829. Retrieved from: http://contemporary-issues.vern.hr/files/1537b89cccb3209491f9a242bb079563.pdf

Krouber, A.L. and Kluckhohn, C. (1952). Culture: A critical review of concepts and definitions. Cambridge: Peabody Museum of American Archeology and Ethnology.

L'Etang, J. (2013). Public relations: A discipline in transformation sociology. Compass, 7, 799-817. doi: $10.1111 /$ soc 4.12072

Lewis, A. (2017). News: Gold for the impossible signing session at Cannes Lions 2017. Retrieved from: https://www.teamlewis.com/us/insights/articles/news-gold-for-the-impossiblesigning-session-atcannes-lions-2017

Negus, K. (2002). The work of cultural intermediaries and the enduring distance between production and consumption. Cultural Studies, 16, 501-515. doi: 10.1080/09502380210139089

O'Connor, J. (2015). Intermediaries and imaginaries in the cultural and creative industries. Regional Studies, 49, 374-387. doi: 10.1080/00343404.2012.748982

Odabaşı, Y. (2012). Postmodern pazarlama. İstanbul: Media Cat Kitapları.

Odabaşı, Y. (2013). Tüketim kültürü: Yetinen toplumdan tüketen topluma. İstanbul: Sistem Yayıncılık.

Oğuz, E. S. (2011). Toplum bilimlerinde kültür kavramı. Edebiyat Fakültesi Dergisi, 28(2), 123-139. Retrieved from: https://dergipark.org.tr/tr/pub/huefd/issue/41213/505402

Oktan, A. (2008). Türk sinemasında hegomonik erkeklikten erkeklik krizine: yazıtura ve erkeklik bunalımının sınırları. Selçuk İletişim Dergisi, 5, 152- 166. Retrieved from: https://dergipark.org.tr/tr/pub/josc/issue/19016/200711

O'Sullivan, T., Hartley, J., Saunders, D., Montgomery and Fiske, J. (1994). Key concepts in communication and cultural studies. London: Routledge.

Özcan, K. (2012). Postmodern örgüt kuramı. Ankara: Gazi Kitapevi.

Palinkas, L., Horwitz, S.M., Green, C.A., Wisdom, J.P., Duan, N. And Hoagwood, K. (2015). Purposeful sampling for qualitative data collection and analysis in mixed methodimplementation research. Adm Policy Ment. Health, 42, 533-544. doi: 10.1007/s10488-013-0528-y

Parsa, A. F. (2004). İmgenin gücü ve görsel kültürün yükselişi. Anadili Dergisi, 33, 59-71. Retrieved from: https://www.researchgate.net/publication/308785296_Imgenin_Gucu_ve_Gorsel_Kulturun_Yukselisi

Radford, G. (2011). Public relations in a postmodern world. Public Relations Inquiry, 1, 49-67. doi: $10.1177 / 2046147 \mathrm{X} 11422143$

Rose, G. (2001). Visual methodologies. London: Sage Publication.

Sartori, G. (2006). Görmenin iktidarı. İstanbul: Karakutu Yayınları.

Soydan, M. (2008). Postyapısalcı bir okumayla eurimages destekli türk filmlerinin çözümlenmesi. (PhD Thesis, Ege Üniversitesi, İstanbul). Retrieved from: https://tez.yok.gov.tr/UlusalTezMerkezi/tezDetay.jsp?id=NI6y5t2xs28Ue_pPvhSeQ\&no=Kt0dKhufla3xk4qayBr8KQ

Stake, R. E. (2005). Qualitative case studies. In Denzin, N. K. and Lincoln, Y. (Ed.) The Sage handbook of qualitative research (p.443-466). CA: Sage. 
Swedish Klaus Heidi made world famous by Lufthansa campaign. (2018, 12 Feburary). Retrieved from: https://www.ddb.com/blog/press-releases/swedish-klaus-heidi-made-world-famous-by-lufthansasprcampaign//?closed=true

The impossible signing session. (2018, 7 January). Retrieved from: https://www.coloribus.com/adsarchive/onlinedirectmarketingcasestudy/unknownadvertiser-theimpossible-signing-session-image-16616365-22519965

Toth, E. (2002). Postmodernism for modernist public relations: the cash value and application of critical research in public relations. Public Relations Review, 28, 243-250. doi: 10.1016/S0363-8111(02)00130-3

Uçan, G. (2012). Post-Modern erkek(lik). CBÜ Sosyal Bilimler Dergisi, 10, 262-271. Retrieved from: https://dergipark.org.tr/tr/pub/cbayarsos/issue/4066/53645

Watson, N. (2006). Postmodernizm ve yaşam tarzları. In S.Sim (Ed.) Postmodern düşüncenin eleştirel sözlü̈̆̈̈ (p. 45-59). İstanbul: Ebabil Yayınları.

Yıldız, N. (2013). Aşk yüzyılı bitti: Aşk’ta, Isş’te, Siyaset'te yeni zamanlar. İstanbul: Doğan Kitap.

Yin, R. (2009). Case study research design and methods. USA: Sage Publications.

Zainal, Z. (2007). Case study as research method. Jurnal Kemanusiaan, 9, 1-6. Retrieved from: https://jurnalkemanusiaan.utm.my/index.php/kemanusiaan/article/view/165

\section{Genişletilmiş Özet}

\section{Amaç}

Halkla ilişkiler alanında farklı paradigmalar olmasına rağmen, baskın olan paradigmanın halkla ilişkileri "yönetim işlevi” olarak tanımlayan "işlevsel paragima" olduğu görülmektedir. Alanda tek bir paradigmanın hâkim olması hem diğer paradgimaların seslerini duyurmalarını engellemekte hem de paradigmaların birbirini besleme potansiyelini azaltmaktadır. Bu makalede halkla ilişkiler ile kültür arasındaki ilişkiye odaklanan sosyokültürel perspektif temel alınmıştır. Ancak halkla ilişkilerin yönetim işlevi de gözardı edilmemiştir. Dolayısıyla sosyo-kültürel paradigma ve işlevsel paradigma birlikte kullanılmıştır. Bu çerçevede makalede halkla ilişkiler hem postmodern kültürü etkileyen hem de (yeniden)üreten kültürel aracı bir meslek olarak tanımlanmıştır. Ancak halkla ilişkilerin kültürel aracıllk işlevinin örgüt lehine "sembolik şiddet" içerdiği savunulmuştur. Makalenin amac1, halkla ilişkiler kampanyalarındaki postmodern kültür özelliklerini araştırmak, halkla ilişkiler mesleğinin postmodern kültürü yeniden(üreten) bir araç olarak tanımlanıp tanımlanamayacağını tartışmaktır.

\section{Tasarım ve Yöntem}

Bu makalede 3 araştırma sorusunun yanıtı aranmaktadur. İlki halkla ilişkiler kampanyaları aracılığıyla hangi postmodern kültür özelliklerinin, nasıl üretildiğidir. İkincisi, halkla ilişkiler kampanyaları aracıllğıyla postmodern tüketim anlayışının nasıl üretildiğidir. Ve son olarak kampanya mesajlarının moderniteyi yapısöküme uğratarak ve meta anlatılara karşı çıkarak çok sesliliği, eşitliği ve özgürlügü sağlayan bir söylem üretip üretmediğidir. Bu kapsamda halkla ilişkiler kampanyaları ve uygulamalarının incelenmesi için çoklu vaka analizi çerçevesinde eleştirel söylem analizi kullanılmıştır. Çoklu vaka analizi genel bir durumu araştırmak için birden çok vakanın ele alınmasıyla gerçekleştirilmektedir. İncelenen vakalar birbirleriyle aynı özellikleri gösterse de göstermese de, bu vakaların incelenmesinin araştırmacıyı konu hakkında daha derinlikli bir 
anlayışa ve kuramsallaştırma yoluna götüreceği düşünülmektedir. Çoklu vaka analizinin seçilmesinin nedeni, amaçlı örneklem yöntemiyle seçilen halkla ilişkiler kampanyaları ve uygulamalarının her birinde "postmodern kültür"ün farklı özelliklerinin (yeniden) üretilmiş olmasıdır. Her vakada aynı özelliklerin bulunması beklenmemektedir. Her vaka kendi içerisinde "postmodern kültürün” nasıl üretildiği bağlamında incelenmiştir. Vakaların bir araya getirilmesiyle halkla ilişkilerin "postmodern kültür” için aracılık rolüyle ilgili bütünlüklü bir anlayış geliştirilmesi amaçlanmaktadır. Her halkla ilişkiler kampanyası ve uygulaması bir "söylem" olarak kabul edilmiş ve analiz birimlerinin incelenmesi için "eleştirel söylem analizi" yöntemi kullanılmıştır. Halkla ilişkiler söylemlerinin örgüt lehine "simgesel şiddet" içerdiği düşünüldüğü için, kampanya söylemlerinde örtük iktidar örüntüleri araştırılmıştır. İncelenen kampanyalar, amaçlı örneklem yöntemiyle en çok veri içeren ve araştırma için zengin içeriğe sahip kampanyalar arasından belirlenmiştir. Bu bağlamda Axe’ı “Erkekler de Ağlar”, Lufthansa’nın “Sen Klaus Heidi Misin? Ve Bol.com’un “İmkansız İmza Günü” kampanyaları incelenmiştir.

\section{Bulgular}

Araştırma sonucunda incelenen halkla ilişkiler kampanyalarının farklı postmodern kültür özelliklerini (yeniden) ürettikleri bulunmuştur. Toplumsal düzeyde yansımasını "bireyselleme", bireysel düzeyde "modüler kimlik” kapsamında gösteren parçalanmanın kampanyalar aracılığıyla (yeniden) üretildiği görülmektedir. "Erkekler de Ağlar" kampanyasında "gözyaşların seni sen yapıyor", "parmak izlerin gibi gözyaşların da sana özel” gibi ifadeler kullanıldığı ve bu ifadelerle duygularını özgürce yaşayabilen erkeklerin "farklı" ve "eşsiz" olacağının ifade edildiği görülmektedir. Sen Klaus-Heidi Misin?” kampanyasında Berlin'de bir yıllık yaşama sponsorluk karşıllğında, bireylerden kimliğin en önemli bileşenlerinden biri olan "isimlerini” değiştirmeleri beklenmektedir.

Kampanyalar aracılığıyla (yeniden) üretilen bir diğer özellik "gösteri”dir. "Gösteri” kavramının yükseldiği dönemde gündelik olaylar ve bildik şeylerin şaşırtıcı bir şekilde sunulması gerekmektedir. Hayret uyandırmayan şeyler, deneyimler ve anlar yok hükmündedir (Balaban, 2014). İncelenen kampanyaların şaşırtıcı, aynı zamanda ilgi çekici oldukları görülmektedir. Kampanyalarda ismin değiştirilmesi, ölmüş biri tarafından kitap imzalanması gibi şaşırtıcı olaylar gerçekleşmektedir.

Simülasyon anlayışının da (yeniden) üretildiği görülmektedir. “İmkânsız İmza Günü” kampanyasında en çok imza alınan yazar robotic kol olmuştur.Bu durum kopyanın daha gerçek hale gelmesinin önemli bir göstergesidir. "Erkekler de Ağlar” kampanyasında klipte ağlayan erkeklerden alınan gözyaşlarının bio-art’a dönüştürülmesi de bu duruma örnek olarak gösterilebilir. Kampanyanın Web sayfasında gözyaşları, çekilen klibe gönderme yapılarak özgürlüğün, hırsın, pişmanlığın, yalnızlığın gözyaşı olarak farklı şekillerde tanımlanmaktadır. Ancak klipte ağlayan erkeklerin birer oyuncu olduğu göz ardı edilmektedir.

Kampanyalar aracıllğılyla (yeniden) üretilen “postmodern kültür” ün aslında moderniteyi yapısöküme uğratarak ve meta anlatılara karşı çıkarak çok sesliliği, eşitliği ve özgürlüğü sağlayan değil, aksine bu anlatıları yeniden üreten ancak -miş gibilik kavramı altında büyüleyen bir söylem oluşturduğu görülmektedir. Aynı zamanda üretilen sembollerin, "simgesel şiddet" unsurları içerdiği, örgüt lehine anlamlar taşıdıkları bulunmuştur.

$\mathrm{Bu}$ çalışmada halkla ilişkilerin "kültürel aracılık" rolü üzerinde durulmuş ve postmodern kültürle bağı kurulmuştur. Halkla ilişkiler kampanyaları aracılığıyla (yeniden) üretilen postmodern kültürün özellikleri göz önünde bulunurulduğunda, bu özelliklerin değişen üretim ve tüketim koşullarına uygun, bu koşullarla uyumlu bir yaşam tarzı, anlama ve düşünme biçimi oluşturduğu görülmektedir. Değişen üretim ve tüketim anlayışında, sistemin devamlılığının sağlanması için ürünlerin henüz kullanım ömürleri bitmeden, yenilerinin satın 
alınması gerekmektedir. Postmodern kültürün özellikleri, toplumun değişen üretim ve tüketim anlayışına daha uyumlu hale getirilmesini sağlamaktadır.

\section{Araştırma Sınırlııkları:}

Araştırmada üç halkla ilişkiler kampanyası incelenmiştir, bu sayının artıılması araştırma sonuçlarının çeşitliliğini artıracaktır

\section{Öneriler}

Halkla ilişkiler alanında gerçekleştirilen çalışmaların önemli bir kısmı halkla ilişkileri örgütsel bir işlev olarak ele almaktadır. Bu durum halkla ilişkiler "kültürel aracı" rolünün gözardı edilmesine neden olmaktadır. Bu çalışma iki farklı paradigma (sosyo-kültürel ve işlevsel paradigm) birlikte kullanılmış. Araştırma tek bir paradigmadan hareketle gerçekleştirilmemiştir. Farklı paradigmaların birlikte kullanılmasının alanine gelişimi için önemli olduğu düşünülmektedir.

\section{Özgün Değer}

$\mathrm{Bu}$ çalışmada iki farklı halkla ilişkiler paradigması birlikte ele alınmıştır. "Postmodern/postmodernite/postmodernizm" kavramları ile "halkla ilişkiler" arasında pek çok kesişim öbeği ve araştırma alanı bulunmaktadır. Bu iki alanı ele alan çalışmaların önemli bir kısmının "postmodernizmi” bir epistemoloji olarak kabul ederek, modern halkla ilişkiler uygulamalarını yapısöküme uğratacak bir araç olarak incelemiştir. Bu makale kapsamında diğer çalışmalardan farklı olarak halkla ilişkiler ve postmodern kültür arasında bağ kurulması amaçlanmıştır.

Araştırmacı Katkısı: Beris ARTAN ÖZORAN (\%100). 